\title{
Some Aspects of IAS Harmonization Process
}

\author{
Dr.Ariet MALAJ, \\ College University of Business Tirana Albania,Vangjel Noti,Tirane
}

\begin{abstract}
The International Accounting Standards Committee (IASC) was established in 1973 to harmonize international accounting standards. The IASC's standards (IASs) are now accepted in some form by numerous stock exchanges, including those in London, Germany, Hong Kong, Singapore, and Switzerland. The US SEC already accepts use of three IASs and has indicated that it may accept all IASs in late 1998. Though accepted by a growing number of stock exchanges, this may not represent individual country's accounting standards. This article investigates the recent progress of international accounting harmonization by examining whether countries' official standards are in compliance with the IASs in the 1990s. Overall, harmonization via IASs appears to increase from 1991 to 1993. However, when the results of the "Comparability of Financial Statements" program became effective in 1995, at least initially, the level of harmonization decreased. This drop is not unexpected given that the 1995 changes eliminated previously approved and practiced accounting methods. This paper provides an introduction to the topic "The Process of International Harmonization of Accounting Standards".

Keywords: Harmonization, International Accounting Standard Board (IASB), International Accounting Standards (IAS), Accounting Standards etc.

DOI: $10.7176 /$ RJFA/11-17-04

Publication date:October $31^{\text {st }} 2020$

\section{Introduction}

The international harmonization process of Accounting Standards started somewhere in the 1960s' and recent developments show that it is still going on. For us it seems interesting to reflect on this process and to ask about the characteristics (driving forces, actors, stages) of it.

The IASB was formed as an international standard-setter in 1973. There is no other organization in our view, with the same efforts. Furthermore, we realized that all our books (without exception) introduced the IASB and not other organizations like the FASB in order to analyze the harmonization process. We knew from the beginning that the IASB is an international standard-setter. We decided not to pre-assume that the role of the IASB is only to develop standards. Therefore, to be open as much as possible, we asked what role the IASB plays in the harmonization process.
\end{abstract}

\subsection{General information}

Does accounting have an international dimension? Many specialists consider accounting "as a tool that helps to measure economic activity". The function of accounting is to provide information about the economic reality that is relevant to economic decisions. Accounting is judged as the language of business. But what language does Accounting speak? When talking about the language of Accounting anyone can conclude that he can speak an international language. So we may ask, how successful has accounting been in establishing itself as an international language?

Professional and technological progress and the transmission of information, people, goods and services have brought the world closer together. Increased international trade and capital flows have spurred increasing economic integration. As a result of these developments, there has been a homogenizing international effect on many customs, practices and institutions. In business life this has led, above all, to a desire to harmonize Accounting Standards between states.

International businesses have not only encountered accounting problems, which end within the borders of one country. When companies cross borders they face new cultures, challenge new laws and different political systems. In addition, international companies can operate with different Accounting Standards.

When Daimler-Benz and Chrysler announced their merger in 1998, it meant not only that two companies from two different countries were merging, but also that two different accounting philosophies were facing each other. The lack of the same Accounting Standards has led, among other things, to problems in comparing financial data. This lack of comparison implies an obstacle to the free movement of capital, just as stockholders may be reluctant to invest in foreign companies, which prepare financial data according to different Accounting Standards.

International companies are facing the problem that Accounting rules are changing around the world. As a result they often have to prepare financial statements twice: once in their own country and according to the rules of their own country and another time abroad according to the rules of other countries. This practice involves the risk that the same problems will be treated differently in different countries.

Another problem with the variety of accounting rules is that companies that would like to be listed on the 
New York Stock Exchange (NYSE) would have to prepare, in addition to national financial data, a financial statement in accordance with US-GAAP. . Such practices mean for companies extra costs, which influence the competition for capital. For investors this confuses which Accounting Standards are appropriate and which result is more reliable.

In recent years, international companies, financial analysts, various international organizations, such as the International Accounting Standards Board (IASB) and other actors should make efforts to achieve a harmonization of Accounting Standards. The aim was to avoid the variety of financial statements, reduce the extra costs (which come as a result of using different financial statements), and attract foreign investors.

\subsection{Problems of the topic on IAS harmonization.}

The process of international harmonization of Accounting Standards began sometime in the 1960s and current developments show that it is still ongoing. It is interesting to think about this process and ask about its characteristics (driving forces, actors, stages).

- What is the process of international harmonization of accounting standards?

In all literature research we found that the harmonization process was extensively described in book texts during the 1980s. Recent developments, activities and statements of actors involved in the harmonization process are described in articles and websites. However, the status quo situation of international harmonization of Accounting Standards has not been described in detail at present. In other words, due to the lack of information on the status quo, I find it necessary to further analyze this area.

- What is the current state of the harmonization process?

During the research I read a lot about the importance of the International Accounting Standards Board (IASB) in the process of harmonizing International Accounting Standards. Therefore, I intend to analyze the role of the IASB in the harmonization process.

What is the role of the IASB in the harmonization process?

\subsection{Purpose}

I consider the process of international harmonization of Accounting Standards as the main development in the field of International Accounting. Due to the importance of this process I decided to dedicate the topic to describe and analyze it. My main goal in this topic is to describe the harmonization process. I would like to give the reader a complete picture of it. As a result, the purpose is to answer the question: What is the process of international harmonization of Accounting Standards, what is the status quo, what is the role that the IASB plays in it?

Thus I contribute to the field of International Accounting by describing the harmonization process from the starting point to the status quo. In other words, the purpose of the topic is to give the reader an overview of the past, present and future developments. He will create an idea of the actors involved in the harmonization process.

\subsection{Field of study}

In the following I would like to give the reader a better understanding of what I would focus the topic on.

The broad field of study is the field of International Accounting. This is the broader framework, which the topic will not cross. In this field I chose the process of international harmonization therefore I placed it in the center of interest.

There are three approaches to systematize the harmonization process. These are illustrated below:

Systematization of the harmonization process

The "who" of harmonization is related to the question: Which institutions are involved in the harmonization process? These are the European Union (EU), the OECD or the IASB. "How" has to do with changes in the imposition and mechanism of sanctions in the harmonization process. These can be, for example, national rules, recommendations, market solutions or international laws. The "what" of the harmonization process aims to explain what is currently harmonized. This can be the main purpose of financial statements, specific rules or definitions. It also operates with questions such as: Who should apply the harmonized rules? Will they be applied at a consolidated financial level or at a single financial level? What types of businesses will apply these rules?)

The theme operates mainly with the "Who" of harmonization. I would like to emphasize that I describe the harmonization process from the perspective of actors who create standards. Which means I'm going to focus more on the actors involved in developing and enforcing International Accounting Standards (IAS).

\subsection{Limitations}

I illustrated above which areas are not considered in this topic. The field of International Accounting is very broad so not all aspects can be covered in this topic. When writing for International Accounting you can specialize in various topics such as: transfer pricing, currency returns or auditing.

However, I will not provide technical descriptions of Accounting rules, standards or practices. Harmonization of Accounting Standards includes the international and regional field. I decided not to write about the regional 
harmonization process. At first I wanted to focus on the harmonization process only in Europe. However, after looking at the initial literature I realized that the European process is at a more consolidated stage than the international one. Therefore, I decided to ask for more about the international harmonization process. In addition, I would like to emphasize that I describe the harmonization process not from the perspective of companies. Thus, I do not consider it as if they impose IASs.

\section{IAS Harmonization.}

\subsection{Perspective}

The purpose of this section is to give the reader an idea of the perspective in which this section was written. In general, two perspectives can be found in the field of research, called Positivism and Hermeneuticism. In the following I will show why I connect this study with the perspective of Hermeneuticism.

This topic aims to illustrate the process of harmonizing Accounting Standards. It is important for readers to get the key concepts and understand the phenomenon of harmonizing Accounting Standards. In order to model this process for the reader, I collected and interpreted existing data. Hermeneuticism focuses more on the interpretation and explanation of written texts. I am aware that attempting to use existing data, and to give explanations and interpretations of interpretations, can be considered a Hermeneutic approximation.

However, at the beginning of my work I considered all the texts on Accounting as a fact. Accounting is something separate from the law. It is made up of rules written in company laws. Therefore, it seemed that the Accounting texts did not allow for interpretations. However, wherever I searched I learned that this is not true. I realized that accounting is influenced by inheritance and opinions and these are not facts or data that have been interpreted, but texts.

Considering this research I will describe the process of international harmonization of Accounting Standards. I limit my study to describing and interpreting the process and explaining the role of the IASB in it. My purpose is not to improve laws or generalize the harmonization process. Since the positive side of science does not see the researcher as "working with a socially observable reality and the end product of such research may be derivatives of laws or generalization of laws" I can not call my positive approximation.

\section{International Practices and IAS harmonization. \\ 3.1 Changes in international accounting practices}

The environment in which a country operates determines the Accounting Practices it uses. Just as different countries have different histories, values and political systems, so too have they had different stages of development of their financial accounting system.

\section{Legal System}

The world of accounting can be divided into those countries that have a legal orientation of accounting and those countries that have a non-legal orientation. Illegal orientation can be found in countries where we use the "common law" system. In countries with such a legal system, accounting does not depend on the law. Accountants (their professional organizations) define the rules of accounting. So, in these countries it is the private sector that sets the accounting rules, not the law. The task of the legal system is to respond to specific cases, and not to formulate general rules for the future.

Legal orientation is found in some countries that use the so-called "codified law". Unlike the "common law" system, this codified system needs to develop in detail the rules for financial reporting and accounting. This means that the accounting rules are incorporated into national law and are of a procedural and descriptive nature. In these countries the role of the law is to describe behaviors that are considered socially acceptable.

\section{Financing system}

The three main external sources of capital are shareholders, banks and the government. It depends on the country instead of which of these resources provides the most capital for companies. In countries like Germany and Italy, banks provide companies with the largest share of capital. In countries like England and the US shareholders provide companies with more capital. While in France and Sweden, the government is the main provider of capital. The diversity of capital resources causes Accounting Practices to vary in order to satisfy the needs of capital providers. In the case of shareholders, providing information is more important than in countries where capital is provided by the government and banks. It is impossible for a company to inform every shareholder with the specific information it needs, because shareholders are a large and disorganized group of people. For this reason financial statements in the UK and US are geared towards giving individual investors the information they need to make decisions about buying or selling shares or bonds of the company. Accounting practices in countries that have banks as the main provider of financing aim to protect banks' investments. This is why in these countries more conservative methods are observed such as overestimation of liabilities and underestimation of assets. In countries where the government is the main provider of funding, there is an orientation of Accounting Practices that favor 
the needs of government planners.

\section{Tax system}

The issue here is to determine to what extent the tax system defines the Accounting system. In countries like the US, the Netherlands and England there is no overlap of tax law and accounting. When accounting standards are developed, the only thing to consider is the transfer of information. Tax issues are not considered in this process. In contrast, in countries like France and Germany, tax and accounting systems are considered the same.

\section{National culture}

National culture also has an impact on Accounting Practices. National culture influences the behavior of accountants, and thus the nature of Accounting Practices. In countries where protection from uncertainty is important, efforts are greater to avoid uncertainty. This means that in the field of Accounting, the rules are usually more explicit, detailed, mandatory, mandatory and rigid.

\section{Other impacts}

Another factor that affects accounting practices can be called the "history accident factor." History accidents refer to the rules of accounting practices that developed as a result of crises, such as the financial crisis that followed the collapse of companies at the beginning of 1920s in the US led to the establishment of the Securities Exchange Commission and stricter accounting rules to protect shareholders.

Economic and political ties have been another factor that has influenced the definition of Accounting Practices. Accounting practices have not only been used in certain countries, but they have also been exported since the beginning of Accounting. For example. the movement of accountants between the US and England led to many similarities in the Accounting system of these two countries. The US, on the other hand, influenced the Accounting Practices of Canada and Mexico. Britain has influenced its former colonies, e.g. India and Pakistan.

As a result of the above factors Accounting Practices vary from country to country. These changes in accounting are the product of a variety of factors of a political, economic and cultural

\section{Tax system}

Tax laws are independent of national Accounting requirements.

The tax law defines the methods of valuation, the methods of recording business transactions and the presentation of financial statements.

\subsection{The process of international harmonization of Accounting Standards}

Harmonization is the process that aims to approximate different systems. In this way the harmonization of International Accounting can be defined as "the process of approximation of Accounting Standards in accordance with such that the financial statements of different countries are prepared according to several common principles of accounting and transparency." Reconciliation can be conceived as a condition under which only a limited number of accounting methods are used. Harmonization means that deviant rules that do not exclude each other can continue to exist next to each other. This means that harmonization does not focus on eliminating change but on reducing rules that are in conflict with each other.

Harmonization can be conceived in two dimensions: material and formal. a) Material harmonization refers to harmonization according to different enterprises. In other words, we are talking about the current application of standards. b) Formal harmonization is related to the similarities and differences between the rules of different countries or different groups.

\section{Reciprocal Recognition}

Mutual recognition means that national financial statements are accepted outside a country, even though they have not been prepared in accordance with the accounting principles of the foreign country.

Opportunity for mutual recognition exists in some countries, such as between the US and Canada. This means that the financial statements of US companies based on the US General GAAP (US Generally Accepted Accounting Principles) system are accepted by Canadian stock regulators. Also, mutual recognition is possible between European countries. The disadvantage of mutual recognition is that the user of the financial statements must be familiar with two different systems of standards. Mutual recognition is possible between countries that have similar Principles of Accounting.

\section{Standardizing}

Another term different from harmonization is standardization. It describes a process by which all participants agree to follow Accounting Practices that are the same or very similar. In a way standardization means that all the practices and principles of Accountability are the same. The terms standardization and harmonization are often 
used in the same context. It should be noted, however, that there is a fundamental difference between these two terms. Standardization is a process during which all countries adopt the method of one country. On the contrary, harmonization means the agreement of different points of view.

\section{Reason to have a harmonization process}

Companies prepare financial statements. It is understandable that international companies are not interested in having different Accounting Standards in every country where they invest. Uniform Accounting standards provide internal and external efficiency for companies. From within multinational companies would increase savings if all their branches used the same Accounting systems. Also, international companies can increase their savings if they do not need to change their financial statements based on different rules in each country where they operate. In other words, access to key financial markets would be facilitated and thus it would be easier to obtain capital from them.

From the point of view of users of financial statements (eg investors, banks or owners), the comparison between different countries or companies becomes easier when there are unified accounting standards.

\section{Role of the IASB (International Accounting Standard Board)}

The IASB is part of the IASC (International Accounting Standard Committee) Foundation. The IASC was established in 1973 by agreement of the leading professional accounting organizations of Australia, Canada, France, Germany, Japan, Mexico, the Netherlands, Britain, Ireland and the United States to coordinate accountingrelated activities. The IASC has autonomy to develop standards and has over 150 members in over 100 countries. The IASB is based in London and is the standard-setting body at the IASC Foundation.

\section{Conclusion}

The IASB was previously known as the International Accounting Standards Committee (IASC) until April 2001, when it became the IASB.

The IASC was originally set up in 1973 and was the sole body to have both responsibility and authority to issue international accounting standards. In 2001, when the IASB took over responsibility for international financial reporting, it took on all of the IASC's standards (which were all prefixed with 'IAS' - e.g. IAS 2 Inventories, IAS 10 Events After the Reporting Period). The IASB amended many of the standards, but then began to issue its own standards, which were known as International Financial Reporting Standards (IFRS). This is why you see standards prefixed with IAS (IASC standards) and IFRS (IASB standards). The term 'IFRS' has become a somewhat generic term that refers to all the standards (both IAS and IFRS)

The IASB was previously known as the International Accounting Standards Committee (IASC) until April 2001, when it became the IASB.

The IASC was originally set up in 1973 and was the sole body to have both responsibility and authority to issue international accounting standards. In 2001, when the IASB took over responsibility for international financial reporting, it took on all of the IASC's standards (which were all prefixed with 'IAS' - e.g. IAS 2 Inventories, IAS 10 Events After the Reporting Period). The IASB amended many of the standards, but then began to issue its own standards, which were known as International Financial Reporting Standards (IFRS). This is why you see standards prefixed with IAS (IASC standards) and IFRS (IASB standards). The term 'IFRS' has become a somewhat generic term that refers to all the standards (both IAS and IFRS).

\section{References}

Publications in text form by the CCC,

IAS / IFRSs issued by the NQF:

IAS 26 - Accounting and Reporting from Pension Benefit Schemes,

IAS 29- Financial Reporting in Hyperinflationary Economies,

IAS 33 - Income per Share,

IAS 34- Interim Financial Reporting

IAS 39- Financial Instruments - Recognition and Measurement; and

IFRS-2- Share-based payments,

IFRS 4 - Insurance Contracts,

IFRS 6 - For the use and assessment of mineral resources,

IFRS - 7 Financial Instruments - Disclosures,

IFRS 8 - Operating Segments

Articles on IAS, related to financial reporting, cost accounting and analysis of financial statements, published in the journal "Accounting, Finance \& Auditing"

Other online materials.

Choi, F .; Mueller, G. (1992): International Accounting, Prentice Hall, New Jersey, $2^{\text {nd }}$ Edition. 
Cooke, S .; Rivat, L .; Faarborg, M .; Pacter, P. (2001): ACCOUNTING STANDARDS, International Tax Review, Vol. 12, Issue 7.

Law on Accounting and Financial Statements no. 9228 dt. 29.04.2004, with changes www.minfin.gov.al, Regulation (CE) n. 1606/2002 of the European Parliament and of the Council, of 19 July 2002

"Guide to International Accounting Principles - 1 The IAS Balance Sheet Editing" A.Portalupi 